Accepted refereed manuscript of:

Freathy P \& Calderwood E (2013) The impact of internet adoption upon the shopping behaviour of island residents, Journal of Retailing and Consumer Services, 20 (1), pp. 111119.

DOI: $\underline{10.1016 / \text { i.jretconser.2012.10.012 }}$

(C) 2015, Elsevier. Licensed under the Creative Commons AttributionNonCommercial-NoDerivatives 4.0 International

http://creativecommons.org/licenses/by-nc-nd/4.0/ 


\title{
The impact of Internet adoption upon the shopping behaviour of island residents
}

\author{
by
}

Eric Calderwood

and

Paul Freathy*

Institute for Retail Studies

Stirling Management School

University of Stirling

Stirling

Scotland

FK9 4LA

j.p.freathy@stir.ac.uk

eric.calderwood@stir.ac.uk

*Contact author 


\section{The impact of Internet adoption upon the shopping behaviour of island residents}

\section{Autobiographical Note}

Paul Freathy is Professor of Retail Management at the University of Stirling and Director of the Institute for Retail Studies

e-mail: j.p.freathy@stir.ac.uk

Tel: 01786467410

Eric Calderwood is a Group Board Director of the Co-operative Group and a part time lecturer at the Institute for Retail Studies, University of Stirling.

e-mail: eric.calderwood@stir.ac.uk

Tel: 01786467398

Address for correspondence

Institute for Retail Studies

University of Stirling

Stirling

Scotland

FK9 4LA 


\title{
The impact of Internet adoption upon the shopping behaviour of island residents
}

\begin{abstract}
Despite numerous studies of on-line shopping behaviour, the impact that the internet has had upon island communities remains largely unexplored. This is despite previous research highlighting the difficulties island residents encounter when attempting to access goods and services. This qualitative, exploratory research study interviews individuals across three UK island groups and examines the extent to which on-line provision has reconfigured the purchasing behaviour of local residents. The findings confirm that internet usage is widespread and that a broad range of products are purchased on-line. However the paper maintains that these findings underplay the significance of e-retailing. The internet has had a much more profound impact upon island consumers and the benefits that are derived from on-line availability extend beyond the reconfiguration of shopping patterns. The findings illustrate that the benefits that have accrued from internet adoption have fundamentally transformed the lives of many individuals. It has acted as a liberating mechanism that has positively impacted upon domestic undertakings and socio-cultural activities.
\end{abstract}

\section{Keywords}

Island Retailing

Internet

Consumer Behaviour

Rural Communities

Shopping Patterns

On-line shopping 


\section{The impact of Internet adoption upon the shopping behaviour of island residents}

\section{Introduction}

While island based communities can differ markedly from each other, they are according to Royle (2001) also subject to a common range of constraints due to their relative insularity. Often these issues include scale diseconomies in all dimensions of economic activity, an overdependence upon external trade, high costs of transportation and other infrastructural limitations. Moreover their economies are often seen as fragile or vulnerable as they may be based on a single or limited range of commercial activities (Bass and Dalal-Clayton 1995).

A dependence upon the importation of consumer goods and services is therefore a common theme linking many island communities. While some products may be locally sourced, there is often a reliance upon products transported from the mainland, from abroad or via a neighbouring island community. In the UK, large, island based, market towns such as Portree (Isle of Skye), Douglas (Isle of Man) and Newport (Isle of Wight) have an established retail sector often with intense competition between local and national retailers. On other, more remote islands, communities may be serviced by a single, multi-functional retail outlet, community shop or social enterprise.

From an academic perspective, the challenges that accompany the retailing and the supply of such goods to island communities, remains a relatively under-researched area. Those studies that have been undertaken have focused upon product supply issues (Calderwood and Freathy 
2011), consumer choice factors (Armstrong et al. 1991; Byrom et al. 2001; 2003; Skerret 1999) or the maintenance of service provision in rural communities (Calderwood and Davies 2006; Mochrie et al. , 2006).

Islands however are spatial entities within their own right and the structure and operation of retailing within each community continues to evolve (Calderwood and Davies 2006). While previous research has identified the limited access many remote communities have to products and services (Skerrat, 1999), the actual pattern of shopping behaviour amongst island residents remains largely unexplored. Moreover, the extent to which internet availability has been responsible for further reconfiguring retail shopping patterns is also under researched. This is perhaps not surprising given the limited level of consumer research that has been undertaken into multi-channel environments (Dholakia et al., 2010).

To partly rectify these issues, the paper has the following aims. First, it will detail the shopping behaviour of island residents and the retail channels employed to access goods and services. Secondly, it will examine how this behaviour has changed over time and identify which product categories are most likely to be purchased via the internet. Finally, the research will consider the benefits that accrue from e-commerce and identify the wider impact that the internet adoption has had upon the lives of island residents.

The paper first provides a review of the literature and details how shopping behaviour has been influenced by the growth of e-commerce. This is followed by a brief discussion on the practical issues of living in an island community and an outline of the methodology used in the research. The empirical findings are then detailed and discussed before a series of conclusions are drawn. 


\section{E-commerce and consumer behaviour}

The growth of the internet and its development as a retail channel has been extensively documented in the academic literature (Dholakia et al. 2010; Kim and Park 2005; Schoenbachler, and Gordon, 2002; Schröder and Zaharia, 2008). Weltevreden (2008) for example notes how in the UK, on-line sales grew by $720 \%$ between 1999 and 2005 . Similarly Hjorthol (2009) maintains that by 2006, 39\% of the population in the UK had ordered goods or services via transactional websites. Significant research also sought to identify who shops on the internet and develop typologies based upon different patterns of consumption (Barnes et al. 2007; Donthu and Garcia, 1999; Ganesh et al. 2010; Hjorthol 2009; Kau et al. 2003; Rohm, and Swaminathan, 2004)

The benefits that are derived from e-commerce are also well documented, for example, Sim and Koi (2002) highlighted the convenience afforded by on-line shopping. Individuals can shop whenever they please and are able to access products unavailable in the local market. Similarly Weltevreden (2006) identified that e-shopping reduced the number of trips an individual needed to physically undertake (which in turn could negatively impact upon established retailers). Using the internet was seen to overcome the pressures associated with bricks and mortar retailing (such as overcrowding, parking and queues) and allowed older, less mobile individuals to access a wider range of goods and services (Larson 2009; Lee et al. 2009). This theme was further developed by Hjorthol (2009) who identified that the availability of the internet changed previously established patterns of shopping behaviour. Individuals are often better informed and use websites for the provision of information as well as the actual purchase of goods and services. 
Certain product categories (e.g. books / DVDs) and services (e.g. flight booking / insurance) have particularly lent themselves to the e-commerce channel (Nielsen, 2010) and as Pookulangara et al. (2011) identify, there remains an extant literature examining the conditions under which individuals switch between various channels. They highlight the complexity of this behaviour and maintain that channel migration within a multichannel environment remains a planned, systematic process. Doherty and Ellis Chadwick (2010) maintained this has resulted in a transformation in the marketplace and provided the opportunity to redress the power balance between consumer and retailer. Although predictions that the internet would lead to conditions of perfect competition may have proven unfounded, it has provided greater transparency and given individuals the opportunity to exert greater influence in the exchange process.

The availability of products and services on-line can have a negative impact upon the local retail economy. For example, Lee et al. (2009) draw parallels between internet retailing and outshopping behaviour. While noted differences do exist, e-commerce represents a form of 'trade leakage' whereby customers purchase products outside of their home town or local area. They note that dissatisfaction with local retail provision is the most common reason for outshopping and this is especially true of consumers in more rural areas (Findlay and Sparks 2008; Lee et al. 2008; Mullis and Kim 2011). Such findings confirm a Shetland Islands report (2004) that noted how respondents considered the local market to be expensive, offer poor quality products and limited service.

As internet penetration continues to rise, a number of studies have attempted to identify why individuals do not shop on-line. Initial research identified security concerns and the fear of fraud if using a personal credit card (Aldridge et al. 1997; Forcht and Fore 1995). Later 
studies noted additional delivery costs, waiting times and the need to physically experience the item as amongst the factors that deterred on-line purchasing (Chatterjee 2010; Pires et al. 2004; Sim and Koi 2002). Related research has also investigated the criteria consumers use when choosing a specific on-line retailer. Some have noted the role of trust and the increasing importance of the brand (Burt 2010; Büttner and Göritz 2008; Huang et al. 2004; Mukherjee and Nath 2007; Pan, and Chiou, 2011) while others have identified operational issues as being an important determinant of loyalty. Policies and procedures relating to delivery times, item substitutions and product returns all have the potential to become sources of competitive advantage (Bonifield et al. 2010; Chatterjee 2010; Doherty et al. 1999; Weltevreden 2008).

As e-commerce becomes increasingly widespread a number of studies have examined whether it is possible to identify patterns of internet usage across different consumer segments (Punj, 2011). Hjorthol (2009) for example noted that individuals under 25 were most likely to use the internet to access information on products and services, while women rather than men displayed a greater propensity to search for cultural activities. In terms of actual purchases, considerable variations across a number of different dimensions have been noted including product category, gender, income and age (Stranahan and Kosiel 2007).

Some uncertainty still remains over the extent to which the internet displays distinct patterns of spatial usage. For example, while Krizek et al. (2005) concluded that location was not an influencing factor, Hjorthol (2009) maintained that individuals in urban areas displayed different purchasing habits from those in more remote areas. Similarly Weltevreden et al. (2008) noted that despite consumers in the more peripheral regions of Holland having the most to benefit from internet shopping, urban consumers were more likely to buy on-line (see 
also Boschma and Weltevreden 2008; Farag et al. 2006; ). The reason for this spatial dimension remains uncertain. Some such as Stoel et al. (2009) suggest that rural consumers may lack the skills and knowledge required to fully derive the benefits afforded by on-line shopping while Fitch (2004) questioned whether usage reflected patterns of socio-spatial inequality.

Despite e-commerce having the potential to save consumers time and reduce the number of shopping trips required, there also remains some debate over the extent to which this actually occurs. Lee et al. (2009) for example found that on-line shopping did not simply act as a substitute for physical shopping and that consumers enjoyed both sets of activities. Similarly Sim and Koi (2002) identified how Singaporean consumers viewed shopping as a form of entertainment and considered on-line retailing to be an additional channel which did not reduce or significantly alter conventional behaviour (see also Weltevreden 2006).

Hjorthol (2009) maintained that 'expressive' factors may influence actual behaviour. Individuals may continue to shop at a particular store for ethical (e.g. it stocked environmentally friendly / organic products) or social reasons (e.g. physically visiting a store as a compensatory mechanism for the lack of a social network). In the context of an island community, expressive factors could play an important influencing role and negate a number of the perceived benefits of on-line retailing. Shopping trips to the mainland could be viewed as experiences in themselves and are uninfluenced by the availability of products on-line. At the same time there may be an ethical / moral obligation to support local businesses in order to maintain a retail presence (which in turn may help overcome the isolation of living in a remote rural community). 
While academic research has demonstrated the advantages that can accrue through internet retailing, it would appear that consumer shopping patterns remain complex. Benefits such as convenience and choice, can be mediated by a number of spatial and social dimensions. On one level, on-line shopping would appear to help redress the balance of power between retailers and consumers, however moral and social pressures may serve to counter any such benefits. Prior to examining the extent to which e-commerce has influenced the shopping behaviour of island residents, the paper will detail some of the unique aspects of being part of such a community.

\section{Island life: practical considerations}

Living and working on an island creates a number of unique challenges for retailers, suppliers and consumers alike. The availability of goods and services otherwise taken for granted amongst mainland communities cannot be guaranteed. The reasons for this are numerous and bodies such as the Rural Development Commission and the Carnegie Trust have drawn attention to the issues of developing and sustaining economies in remote locations (RDC 1994; Carnegie 2007; 2008). Such research has highlighted the difficulties involved in creating a retail presence in rural areas as well as the challenges of sustaining a viable supplier base.

Supplying an island community from the mainland can be a complex process. Byrom et al. (2001), for example, identified a number of product related issues linked to the remoteness and rurality of the islands. Not only was it more expensive for suppliers to deliver products, factors such as the weather, sailing times and distance to market all influenced the range, the price and the availability of the offer (see also Freathy and Calderwood 2011). 
Byrom et al. $(2001 ; 2003)$ also note that the specific demands of operating in a remote location have required many businesses to adopt eclectic growth strategies. They identify a 'funnical' model of development whereby a retailer may stock a broad (and diverse) product range, operate symbol group membership or diversify into non core areas (such as petrol stations, cafes and mobile shops). In addition, channels such as mail order allow local products such as jewellery and garments to be sold to a world-wide audience. Such findings reinforce a body of work that has identified the practical constraints placed upon organisational growth through both location and scale (Binet and Wilson,1997; Jussila et al. 1992).

Population decline across many UK islands is not new (Mewett 1983) and many communities have long been faced with dwindling populations as individuals migrate to the mainland (Morrison and Clark 2011; Prattis 1982). While in recent years settling on an island has been heralded as an alternative lifestyle choice, many islands continue to experience an overall decline in their total populations. Moreover, the demographics remain skewed as those individuals who remain are often of an older working age or have already retired. For example, the population of the Outer Hebrides is projected to decline by 5\% between 2006 and 2031, while those of working age are predicted to fall by $11 \%$ (Comhla Airson Nan Eilean 2011).

What remains unclear is the extent to which these supply and demand side factors limit access to certain product categories and constrain consumer choice. Skerrat (1999) noted issues of limited availability and the poor quality of fresh products as factors negatively influencing the diets of island inhabitants. Moreover the local retail provision was identified 
as being more expensive and more limited than on the mainland. While undoubtedly the access individuals have to goods and services will have changed since Skerrat's (1999) study, how individuals shop, where they shop and the primary channels used to access goods and services remains under researched.

Table 1 about here

As Table 1 illustrates, many on-line retailers now offer delivery to island communities, although as is also demonstrated, the terms and conditions attached to this provision varies significantly. For example, clothing retailers appear to mirror their mainland service guarantees quite closely and many do not charge extra for island deliveries. In contrast, a number of DIY and furniture retailers do not deliver to the islands or else charge for the additional carriage. Several companies appear to maintain a more ad hoc approach to service provision. For example, IKEA state:

"We currently do not deliver on-line to Scotland however our store in Edinburgh may be able to help if you live in Scotland." (www.ikea.com)

In summary, while the influence and benefits of on-line retailing upon both urban and rural communities has been examined, the impact of e-commerce upon island residents remains largely unexplored. This gap in the literature is perhaps surprising given the unique demands of living within an island community and the potentially significant role internet adoption can have upon consumer shopping patterns.

\section{Methodology}


As noted at the outset of this paper, island communities differ significantly in their physical size, their populations and their level of retail development. The first objective was therefore to categorise the various islands based upon their level of retail provision. For the purposes of this research three types of island were identified (Table 2).

Table 2 about here

The first category comprises those islands large enough to sustain a national multiple presence and due to their size, accommodate a variety of organisational forms (convenience stores, supermarkets and superstore) and fascias. Typically these islands have both an urban and rural catchment area as well as a number of independent retail operators (Type One).

Whilst having a population that can sustain a retail presence, a number of smaller islands around the coast of the UK have no national multiples and are serviced by one or more independent operators, a community group or a social enterprise (Type Two). These businesses typically support smaller, more dispersed island communities and may occupy multiple roles (Byrom et al. 2001; Freathy and Calderwood 2011). Finally, despite having a permanent population, a number of islands within the UK have no established retail provision. These communities rely upon products being ordered and transported by boat from the larger islands or local residents making the trips themselves (Type Three).

To understand whether on-line retailing has reconfigured the shopping behaviour of island consumers, the study focused upon residents of Type One and Type Two islands. The rationale for choosing Type One islands was to determine whether the existence of an established retail presence had any mediating effect upon an individual's propensity to use 
the internet (and vice versa). Moreover, each of the Type One islands chosen supported an urban and rural catchment area and the research sought to identify whether internet usage was influenced by an individual's proximity to the main conurbation. The inclusion of respondents from Type Two islands provided the opportunity to explore whether shopping behaviour was influenced by expressive or social constructs (Hjorthol 2009).

Due to the complexity of consumer shopping patterns, a qualitative methodology was deemed most appropriate (Eisenhardt, 1989). The research comprised a series of semi structured interviews with island residents with each individual narrating their own personal shopping experiences and elaborating where necessary. The research aimed to construct a picture of how individuals shopped and to identify specific patterns of internet usage across a range of product categories.

Three island groups were chosen for the study - the Isle of Man, the Outer Hebrides and the Northern Isles of Scotland. Whilst all contained Type One islands, the latter two also contained Type Two islands. All three locations had at least one island with an urban and rural catchment area. To identify whether any spatial patterns of internet usage could be identified on Type One islands, the research chose communities at varying distances to the main town. Interviews were therefore undertaken in two rural communities that were 59 miles and 35 miles from the urban centre (approximately two hours and one hour drive time). Each had their own local (independent) grocery store that sold a limited range of fresh, chilled and ambient goods. The third group of interviewees lived less than 15 miles from the main town (a maximum 25 minutes drive time). The objective of including this group of individuals was to establish whether proximity to the main conurbation influenced shopping patterns. Altogether 12 interviewees lived more than 50 miles from the nearest large town, 
14 lived between 15 to 50 miles away and 9 lived within 15 miles. In addition, three individuals living on Type Two islands were interviewed. One island was located one and a quarter hours sailing from the main island whilst another was a thirty minute sail with a further 20 miles drive to the town.

Altogether thirty eight persons were interviewed with over 35 hours of qualitative research material being recorded. Thirty interviews were undertaken face to face with a further eight being conducted by telephone. All the data were subsequently transcribed and analysed with key themes being identified through the use of established content techniques (Hsieh and Shannon 2005). As Lindebaum and Cassell (2010) note, through an iterative process of reading and re-reading the collected data, the aim of this approach is to take fragments of data and construct a storyline that provided a collective coherence. Such an approach is also consistent with the work of Currie and Brown (2003) and Ylijoki (2005). The total number of interviewees was deemed sufficient for this exploratory study, as by the end of the research, recurrent themes and issues were identified (Ahrens and Dent, 1998; Strauss and Corbin, 1988). Interviews were conducted at a variety of locations including a cafe, a community centre and the respondents place of work.

\section{Findings}

The first objective was to identify how island residents accessed goods and services (Table Three). The research found that while mail order catalogues had traditionally been the primary method of sourcing products not available on the islands, this channel was considered to be less important today. Similarly Product Fairs had also declined in popularity. Fairs had been a feature of island shopping provision and involved companies 
such as Marks and Spencer, Mothercare, Land of Leather and Debenhams occupying parts of a local hotel for two - three days and bringing over a selection of merchandise. Although still held today, these fairs were considered to have little attraction with one respondent noting they had become "dumping grounds" for products that could not be sold elsewhere.

Table 3 about here

In the face of this change, the research sought to determine whether individuals had migrated to the on-line channel and how the internet was being utilised. Some level of e-commerce activity was identified amongst all respondents. Only one individual interviewed did not have a computer or access to the internet. This was due to the remoteness of her property and not having a phone line installed. This situation was about to be rectified and in the meantime she used a colleague's computer and accessed the internet via the local library.

Only two respondents did not purchase on-line and these individuals used the internet to gather information on products and services. Within island communities there exist many extended families and even amongst those who maintained that they infrequently bought items over the internet, other members of their family often did so on their behalf.

As one respondent noted:

"I'm not really that into computers, I have a look in the catalogues and on the websites and if I see anything I like, my daughter gets it for me on her computer... I pay mind you."

In terms of what was purchased on-line, the research identified a wide array of products and services and it was difficult to identify any category that lent itself exclusively to one retail 
channel. The shopping behaviour of respondents was complex with individuals often expressing polarised opinions (Table Four).

Table 4 about here

Island residents continued to use the main towns for a variety of reasons. For example, two respondents noted a gift shop in Stornoway that stocked local Hebridean jewellery. As the products were unusual and could not be found easily on the mainland it made a visit worthwhile. The second reason for using local retailers revolved around the issues of convenience and service. As one respondent maintained:

"When your washing machine breaks down or your fridge stops working you need to get a replacement straight away. If this happens I just go into town to see what is available."

A number of respondents also stated that they would purchase electrical / computer items from local retailers even if they were more expensive. This was due to individuals being unconvinced that virtual / mainland retailers would be able to service the product should anything go wrong. Although it was noted that a local retailer may take a couple of days to arrive, this was considered preferable to having to arrange repairs via a mainland provider.

A strong preference to use local retailers was also expressed when undertaking personal 'project based' purchases such as fitted kitchens, carpets and bathrooms. Respondents noted that an element of expertise and service was needed in order to identify any issues / potential problems that may arise. While it was possible to source goods over the internet, it was felt 
that the need to discuss requirements and physically examine products prior to purchase was necessary.

The third objective of this study was to identify the primary benefits that island residents derived from internet availability. While many of the advantages identified in this research mirror those of previous studies, within an island context these advantages appear to be particularly significant.

Financial Savings: Every individual interviewed was able to identify at least one product or service that could be sourced cheaper via the internet (in practice most were able to identify numerous items). For example, by purchasing bed linen and soft furnishings on-line it was possible to save up to $50 \%$ on island prices and if individuals were able to wait for an on-line sale, then further savings were possible. Similarly white goods such as dishwashers and washing machines could be sourced more cheaply with savings of up to $25 \%$ on island prices being quoted.

However, while savings could be made, it was also noted that any advantage could be immediately offset by the cost of postage and carriage to the islands. Indeed, the retailer's internet delivery and returns policy appeared to be a crucial factor in determining whether respondents would purchase from a particular website and, reinforcing Table 1, the research was able to identify significant differences between on-line provider. For example, one clothing retailer provided free delivery and return and, if goods were ordered on the Monday, they were delivered by the Wednesday. In contrast, numerous other examples were provided where the delivery cost had been prohibitive (for example an infra red thermometer costing $£ 49.99$ had a $£ 90$ delivery fee and a 90 p dog chew had a $£ 6.00$ postage charge). While it was acknowledged that there were disadvantages in not being able to physically see and touch 
some products prior to purchase (for example clothing), a free delivery and returns policy compensated for this. It was also noted that many families had a tradition of purchasing clothing items from catalogues and were familiar with not trying on products prior to purchase.

A number of respondents voiced their frustration with retailers who did not provide clear guidelines on how they managed orders to an island address and whether there were additional costs involved. As a consequence it was often difficult to accurately gauge the potential savings to be made. As one respondent commented:

"I bought a set of bar stools and paid for them in full on-line. I put in HS5 [the post code] and it said about two weeks to deliver. A week later I got a call to say that there had been a mistake and that they did not deliver to the islands and that they would have to refund my money. That was bad enough but about four weeks after that, I got a call from Inverness to say that my stools were in the distribution depot and how did I want to pay to have them delivered."

A second respondent noted how one retailer had made an almost ad hoc decision not to deliver a trampoline to her home. Despite the fact that its website stated that it did deliver to her island, its size and weight had led the retailer to phone up and cancel the order. This was despite the same company having previously delivered a number of smaller orders to the same address.

Time Savings: Not having to travel long distances in order to shop was a primary benefit for residents in the more remote communities. For those who used public transport the time saved could be significant. For example, a trip between Leverburgh and Stornoway in the Outer Hebrides (59 miles one way) could take as long as three hours by bus. As staying overnight was not considered an option, the time available to shop was limited as individuals 
had to make the return journey. As a consequence, shopping trips had to be carefully planned, the numbers of stores visited was limited and excursions were frequent.

In the more remote rural communities the research identified a symbiotic relationship between local retail provision and e-shopping behaviour. Individuals who had access to a good quality, broad based grocery offer were most likely to have reconfigured their shopping behaviour. The need to purchase food and other staple items had been the primary reason to shop in the main town. Once having travelled to the town, respondents would also buy other products. This had now changed and as one respondent commented:

'I get all my groceries from An Clachan \{the local shop\}. Their fruit and veg is great, unless it is urgent I get most other things on line or from a catalogue. I used to go up to Stornoway once every couple of weeks, now I only go up about once a month.

This view was typical and although the actual impact upon the number of journeys made did vary, the availability of local grocery provision combined with internet access, reduced or even removed the requirement of residents in more remote communities to travel to the main town.

Choice and Availability: The greater choice and availability afforded by e-commerce was another advantage identified by the respondents. Many individuals had traditionally undertaken the bulk of their shopping through existing stores or via a catalogue. The internet now allowed individuals to access a wider variety and range of products and to be better informed prior to the purchase decision. In addition, the availability of specialist websites allowed consumers to purchase goods that were previously difficult to source or unobtainable on the islands. For example, ordering CD / DVDs on-line meant that individuals would receive the latest releases before they were available from local retailers. 
The availability of specialist websites also allowed individuals to better pursue hobbies and interests. For example, one respondent noted how she had been able to take up cross country running because of the internet. The island only had one small sports store which was over 40 miles from where she lived and the range of equipment was very limited. Although she had bought some items from a catalogue this was not considered satisfactory. The benefit of the internet was that it provided access to the latest products and brands.

More fundamentally, on-line availability had served to partly redress the power balance between consumer and retailer. A number of respondents highlighted their dissatisfaction with the retail provision on the islands and maintained that quality standards were often lower, customer service was poor and product knowledge was limited. The lack of choice however had meant that individuals were often compelled to buy what was available at the price that was being asked. One respondent felt that he was:

"being held hostage by the local retailers .... who try to pass everything off as quality".

Evidence suggests that this situation had begun to change, for example, one respondent had costed oak furniture on-line and only agreed to purchase from a local retailer once they had agreed to match the internet price and not charge for carriage.

Improved Shopping Experience: The research revealed a tradition amongst island residents of visiting the mainland at least once a year. Typically this was at Xmas or prior to the start of the school term in September. Often the primary objective of these visits was to purchase 
products that households anticipated they would need over the forthcoming six / twelve months. As one respondent explained:

"We did not shop, we raided the stores. You have so little time and there are so many things that you needed. You had to know what you were doing and what you wanted. We just spent a fortune stocking up"

A number of disadvantages were identified with this approach. First, undertaking such a large numbers of purchases on a single trip would often impact upon cash flow. Families had to save for the occasion and there was always a concern about over spending. Secondly, the process could often lead to unnecessary purchases. It was not always possible to predict the exact number of items that were needed and children's clothing was identified as especially problematic. When trying to forecast the number of school shirts, shoes and trousers needed, it was relatively easy to over purchase or miscalculate the correct number of sizes that would be required.

The internet had fundamentally altered this pattern of shopping. Island residents were now able to purchase products on-demand and avoid the danger of over buying. Individuals could adopt a 'just in time' rather than 'just in case' approach and if anyone did over buy, the product could be sold via a transactional website such as e-bay. This helped with the household budget by spreading purchases over the entire year and unlike scheduled visits to the mainland, it was often possible to delay purchases until retailers had begun their on-line sales.

It was also noted that while many residents continued to visit the mainland, the primary purpose of these visits had altered. The emphasis was less upon stocking up on essential items and was viewed more as a short 'get away' break. Those respondents who continued to shop off the island felt that the focus was more upon leisure and speciality shopping and the 
trip was often combined with a visit to friends and relatives, a visit to the theatre or some other form of entertainment. As one respondent commented:

"What I like to do is visit some of the big department stores ...There are some things that you have to see and feel before you buy. I do not have to order it there and then .. I can shop around and do it later on-line.."

For those who wished to avoid the queues and the crowds at times such as Xmas, the internet had completely removed the need to travel to the mainland. As one respondent noted:

" Last year I bought everything on-line. It is really handy if you have friends on the mainland...I ordered Scottish hampers from a website and had them delivered directly to them. They weren't that expensive and they arrived in good time."

\section{Conclusions}

As noted at the outset of this paper, this research was designed to provide an initial investigation into the influence of the internet upon the shopping patterns of island residents. It is therefore exploratory in nature, confined to a limited sample of respondents and covers only a small number of islands. The findings may not be representative of the wider population and the results cannot be generalised. Despite these limitations, a number of conclusions can be drawn that assist in the development of a larger, more representative study.

Reflecting a recognised trend (Larson, 2009), internet usage on UK islands appears to have become widespread and constrained only by the lack of an established, technical infrastructure (Kellerman 2010). The overwhelming majority of respondents interviewed in this research used the internet for retail purchases and few could identify any negative aspects 
of its adoption. The concerns over security noted by Aldridge et al. (1997) and Forcht and Fore (1995) were largely absent and contrary to Sim and Koi (2002), a growing willingness to 'buy before you try' was noted. As many individuals were accustomed to long waiting times, Chaterjee's (2010) issues with product fulfilment were not realised. Respondents did note dissatisfaction with the additional shipping costs associated with on-line delivery although this was directed more towards individual retail sites rather than a criticism of the channel itself.

Previous research identified the benefits of internet shopping and this study reinforced many of these findings (Lee et al. 2009; Larson 2009). Consumers noted the cost and time savings that could accrue from purchasing on-line and the overall level of convenience that ecommerce afforded. However, it is the scale of these benefits more than anything else that remains one of the most significant findings from this research. For many island residents a shopping trip to the town or the mainland was seen as a necessary but expensive and time consuming exercise. The ability to avoid such journeys combined with the familial and social benefits that were shown to accrue illustrates that the impact of on-line availability extends well beyond the actual shopping experience. While e-commerce appears to provide a valued alternative retail channel its effects have therefore been more profound, arguably having a transformational role in the way in which island residents are able to live their lives. The internet has acted as a liberating mechanism by not only removing time consuming, domestic undertakings but also allowing islanders to engage in a range of previously unavailable socio-cultural activities.

The ability of the internet to fundamentally transform the lives of island residents was further demonstrated through the marketing exchange process. Doherty and Ellis-Chadwick (2010) 
noted how in the future there is likely to be a significant struggle for power between retailer and consumer. The findings demonstrated that by reconfiguring shopping behaviour, on-line provision had helped rebalance this relationship. Providing individuals with greater choice, more information and increased pricing transparency not only enhanced their negotiating leverage but also allowed individuals to better control budgets, cash flows and household expenditure.

The extent of this transformation was, however, shown to be partly dependent upon external factors over which the individual has little control. Hjorthol (2009) maintained that shopping behaviour could be mediated by social constructs and the research did note that in the more remote island communities, retail provision reflected a 'funnical' model (Byrom et al., 2001; 2003). The retail outlet typically had a wide product mix, a cafe, a petrol station and the potential to act as a focus for social activities (see also Jussila et al. 1992). While the internet was used to source specialist foods and wines from the mainland, the local store was used for the purchase of food, staple goods and other everyday household items. As there was almost no on-line grocery provision on the islands, the internet had not acted as a substitute channel for these products. The shopping behaviour of island residents was however mediated by the quality and consistency of the local grocery offer. Where this provision met expectations, there was little requirement to travel to the main town to shop and a greater propensity to use e-commerce. If the offer was considered to be poor, individuals were more likely to travel into town and shop for a range of goods. This symbiosis between the local store and the level of internet usage demonstrates a complex interrelationship between physical and virtual retail provision and is perhaps one of the most revealing findings from this investigation. 
From a consumer perspective a number of future research issues arise from this study. First, it remains uncertain whether the opportunity for individuals to engage in new interests and hobbies is indicative of a broader set of social benefits derived from e-shopping. Additional research may help determine whether such activities have led to the development of informal networks and the reversal of some of the more negative 'expressive' factors identified by Hjorthol (2009). Secondly, the ability of island residents to reconfigure their patterns of financial spending may be seen as a form of economic empowerment brought about by the flexibility and control provided by e-commerce. The extent to which similar, household budgetary activities have relevance outside of island communities remains unclear. Thirdly, the research identified a complex pattern of shopping behaviours and the importance of local grocery provision upon consumer store choice criteria. The degree to which such factors determine mobility patterns in remote mainland communities again merits further investigation.

Finally, the results from this research study also identify a number of on-going strategic issues for both island and mainland retailers. Weltevreden (2006) identified the potential of the internet to impact upon city centre stores while Mullis and Kim (2011) noted the importance of relationship building to prevent outshopping behaviour. Both suggested developing specific strategies targeted at those individuals who do not shop in their local community. Similar challenges would appear to be afforded in the context of this research. Respondents indicated they were more likely to use a local provider when an element of risk or uncertainty was involved in the purchase decision. Such findings suggest that island stores could seek to create differentiation and build loyalty through customer service and after sales support. Having access to local, expert IT advice or being able to consult a tradesperson was identified as an added value provision that respondents considered important. 
For on-line retailers, there remains the need to understand how the e-shopping behaviour of island consumers will evolve. Doherty and Ellis-Chadwick (2010) maintain that with the growth of social media, the internet will continue to remain the focus of market competition. Many respondents displayed an awareness of the varying terms and conditions associated with purchasing from individual websites and while some retailers have developed a strong level of customer loyalty amongst island residents, other providers had been less successful. Poorly defined carriage policies or the refusal to deliver to island addresses serves to undermine the effectiveness of a retailers web based strategy. Such a finding further supports the notion that operational aspects of an e-commerce operation can be used as a source of competitive advantage (Bonifeld et al. 2009; Doherty et al. 1999; Weltevreden 2008)

In conclusion therefore, the impact that on-line shopping has had upon island communities would appear to be profound. It represents more than just an alternative retail channel and has both empowered and liberated the way in which residents are able to live their lives. As one respondent commented:

"Living here would not be as comfortable without the internet ... it has changed life for the better" 


\section{References}

Ahrens, T. and J. Dent (1998). 'Accounting and organizations: realizing the richness of field research', Journal of Management Accounting Research, 10, pp. 1-39

Aldridge, A., White, M. and Forcht, K. (1997) Security considerations of doing business via the Internet: cautions to be considered, Internet Research, 7 (1) pp.9 - 15

Armstrong, H., Johnes, G. and McBean, A. (1991) Consumer Goods and Energy Prices on the Isle of Man, Management Research News; 14 (7) 31-35

Barnes, S., Bauer, H., Neumann, M. and Huber, F. (2007) Segmenting cyberspace: a customer typology for the internet, European Journal of Marketing 41 (1/2) 71-93

Bass, S. and Dalal-Clayton, B. (1995) Small island states and sustainable development: Strategic issues and experience Environmental Planning Group, International Institute for Environment and Development

Binet, T. and Wilson, N. (1997), "Developing niche product supply chains in the UK grocery market: lessons from a niche player", Supply Chain Management: An International Journal, 2 (1) $7-10$

Bonifield, C., Cole, C. and Schultz, R. (2010) "Product Returns on the Internet: A Case of Mixed Signals?" Journal of Business Research 63(9-10) 1058-1065.

Boschma, R. and, Weltevreden, J. (2008), "An evolutionary perspective on Internet adoption by retailers in the Netherlands", Environment and Planning A 40 (9) 2222 - 2237.

Burt, S. (2010), "Retailing in Europe: 20 years on", International Review of Retail, Distribution \& Consumer Research, 20(1) 9-27

Büttner, O. B. and Göritz, A. S. (2008), Perceived trustworthiness of online shops, Journal of Consumer Behaviour, 7: 35-50.

Byrom, J., Medway, D. and Warnaby, G. (2003) Strategic alternatives for small retail businesses in rural areas, Management Research News; 26 (7) 33-49

Byrom, J., Medway, D. and Warnaby, G. (2001) Issues of provision and "remoteness" in rural food retailing: A case study of the Southern Western Isles of Scotland, British Food Journal, 103 (6) 400-413

Calderwood, E. and Davies, K. (2006), 'The impact of community co-operatives on shopping behaviour in rural communities in Scotland,' Review of International Co-operation, 99 (1) $53-62$

Calderwood, E. and Freathy, P. (2011) Challenges in the supply of perishable products to island communities, The International Review of Retail, Distribution and Consumer Research, 21(2) 145 - 160 
Carnegie UK (2008) 'Bearing Fruit- Good Practice in asset-based rural community development', Development Trusts Association, Carnegie Trust UK, Dunfermline

Carnegie UK (2007) 'A Charter for Rural Communities- The final report of the Carnegie Commission for Rural Community Development', Carnegie Trust UK, Dunfermline

Comhla Airson Nan Eilean (2011), Factfile - Socio-Economic Review (December 2009), available at http://www.cne-siar.gov.uk/factfile/socioeconomicoverview.asp, last accessed 2nd June 2010

Chatterjee, P. (2010) Causes and consequences of 'order online pick up in-store' shopping behavior The International Review of Retail, Distribution and Consumer Research, 20 (4) $431-448$

Currie, G,. and Brown A. (2003) A narratological approach to understanding processes of organizing in a UK hospital. Human Relations; 56: 563-586.

Dholakia' U., Kahn, B., Reeves, R., Rindfleisch, A., Stewart, D. and Taylor' E. (2010) Consumer Behavior in a Multichannel, Multimedia Retailing Environment, Journal of Interactive Marketing

Doherty, N. and Ellis-Chadwick, F. (2010) "Internet retailing: the past, the present and the future", International Journal of Retail \& Distribution Management, 38 (11/12) 943 - 965.

Doherty, N. and Ellis-Chadwick, F and Hart C. (1999) Cyber retailing in the UK: the potential of the Internet, International Journal of Retail \& Distribution Management, 27 (1) $22-36$.

Donthu, N.,and Garcia, A. (1999), "The Internet shopper", Journal of Advertising Research, 39 (3) $52-8$

Eisenhardt, K. M. (1989). 'Building theories from case studies research', Academy of Management Review, 14, 532-550

Farag, S., Weltevreden, J., van Rietbergen, T., Dijst, M., and van Oort, F. (2006), "Eshopping in the Netherlands: does geography matter?" Environment and Planning B: Planning and Design 33(1) 59 - 74

Findlay, A. and Sparks, L. (2008) Weaving new retail and consumer landscapes in the Scottish Borders, Journal of Rural Studies 24 (1) 86-97

Fitch,D. (2004) Measuring convenience: Scots' perceptions of local food and retail provision, International Journal of Retail \& Distribution Management, 32 (2) 100-108

Forcht, K and Fore, R. (1995) Security issues and concerns with the Internet, Internet Research: Electronic Networking Applications and Policy 5(3) 23-31

Ganesh, J., Reynolds, K., Luckett, M. and Pomirleanu, N.(2010) Online Shopper Motivations, and e-Store Attributes: An Examination of Online Patronage Behavior and Shopper Typologies Journal of Retailing 86 (1) 106-115 
Hjorthol, R. (2009) "Information searching and buying on the Internet: travel-related activities?" Environment and Planning B: Planning and Design 36(2) 229 - 244

Hsieh, H.-F., \& Shannon, S.E. (2005). Three approaches to qualitative content analysis. Qualitative Health Research 15 (9) 1277-1288

Huang, W.-y., Schrank, H. and Dubinsky, A. J. (2004), Effect of brand name on consumers' risk perceptions of online shopping, Journal of Consumer Behaviour, 4: 40-50

IKEA (2011) 'What is shop on-line' http://www.ikea.com/ms/en_GB/customer_service/shop_online/what_is_shop_online.html last accessed June 7th 2011

Jussila, H., Lotvonent, E. And Tykkylainen (1992) Business Strategies of Rural Shops in a Peripheral Region, Journal of Rural Studies, 8 (2) 185-192,

Kau, A.Tang, Y. and Ghose, S. (2003) 'Typology of online shoppers' Journal of Consumer Marketing, 20 (2) 139-156

Kellerman A, (2010), "Mobile broadband services and the availability of instant access to cyberspace" Environment and Planning A 42 (12) 2990 - 3005.

Kim, E. and Kim, Y. (2004) Predicting online purchase intentions for clothing products, European Journal of Marketing, 38 (7) 883 - 897.

Kim, J. and Park, J. (2005) "A consumer shopping channel extension model: attitude shift toward the online store", Journal of Fashion Marketing and Management, Vol. 9 Iss: 1, pp.106 - 121 .

Krizek, K. J., Li, Y., and Handy, S. L. (2005). Spatial attributes and patterns of use in household-related information and communications technology activity. Transportation Research Record, 1926, 252-259.

Larson, M. (2009) Issues Monitor, Sharing Knowledge on the Retail Industry, KPMG International, January, Volume Two, http://www.kpmg.com/Ca/en/IssuesAndInsights/ArticlesPublications/Documents/Issuesmonit orRetailVol2Jan09.pdf (last accessed 4th October 2011)

Lee, D., Paswan, A., Ganesh, G. and. Xavier' M. (2009) Outshopping Through the Internet: A Multicountry Investigation, Journal of Global Marketing 22(1) 53 - 66

Lee, S., Johnson, K. and Gahring, A. (2008) "Small-town consumers' disconfirmation of expectations and satisfaction with local independent retailers", International Journal of Retail \& Distribution Management, 36 (2) 143 - 157.

Lindebaum, D. and C. Cassell (2011). A Contradiction in Terms? Making Sense of Emotional Intelligence in a Construction Management Environment. British Journal of Management, 23 (1) pp. 65-79. 
Mewett, P. G., (1983) Economic brokerage and peripheral underdevelopment in the Isle of Lewis, Sociological. Review, 31, 427-52

Mochrie, R., Galloway, L. and Donnelly, E. (2006) "Attitudes to growth and experience of growth among Scottish SMEs", International Journal of Entrepreneurial Behaviour \& Research, 12 (1), 7 - 20

Morrison, P. and Clark A (2011), "Internal migration and employment: macro flows and micro motives" Environment and Planning A 43 (8) 1948 - 1964.

Mukherjee, A., Nath, P. (2007), "Role of electronic trust in online retailing", European Journal of Marketing, 41 (9/10) 1173-202

Mullis, K. and Kim, M. (2011) Factors determining inshopping in rural US communities: Consumers' and retailers' perceptions International Journal of Retail \& Distribution Management, 39 (5) 326-345

Nielsen (2010) Global Trends in Online Shopping A Nielsen Global Consumer Report, http://hk.nielsen.com/documents/Q12010OnlineShoppingTrendsReport.pdf, last accessed $4^{\text {th }}$ October 2011.

Pan, L-Y. and Chiou, J-S. (2011) How Much Can You Trust Online Information? Cues for Perceived Trustworthiness of Consumer-generated Online Information, Journal of Interactive Marketing 25, (2) pp.67-74.

Pires, G., Stanton, J. and Eckford, A. (2004) Influences on the perceived risk of purchasing online, Journal of Consumer Behaviour 4: 118-131

Pookulangara, S., Hawley, J. and Xiao, G. (2011) Explaining consumers' channel-switching behavior using the theory of planned behavior Journal of Retailing and Consumer Services, $18,(4)$, pp.311-321.

Prattis, J. (1982) Unemployment and Job Creation: A Case Study from the Western Isles of Scotland, Management Research News, 4 (3) 16-20

Punj, G. (2011) Effect of Consumer Beliefs on Online Purchase Behavior: The Influence of Demographic Characteristics and Consumption Values, Journal of Interactive Marketing , 25, (3), pp.134-144.

Rohm, A., and Swaminathan, V. (2004). A typology of online shoppers based on shopping motivations. Journal of Business Research, 57(7) 748 - 757

Royle, S.A. (2001) A Geography of Islands: Small Island Insularity, Routledge: London

Rural Development Commission (1994) Village Shops Mean Business, Rural Development Commission, Salisbury

Schoenbachler, D. and Gordon, L. (2002) "Multi-channel shopping: understanding what drives channel choice", Journal of Consumer Marketing, 19 (1), pp.42 - 53 
Schröder, H and Zaharia, S. (2008) Linking multi-channel customer behavior with shopping motives: An empirical investigation of a German retailer, Journal of Retailing and Consumer Services, 15, (6), pp.452-468.

Shetland Islands Council (2004) Shetland Islands Shopping Survey 2003, Shetlands Islands Council

Sim L. and Koi S. (2002) Singapore's Internet shoppers and their impact on traditional shopping patterns, Journal of Retailing and Consumer Services, 9(2). 115-124

Skerratt, S. (1999) Food availability and choice in rural Scotland: the impact of "place", British Food Journal, 101 (7) 537-544

Stoel, L, Jeong, S. and Ernst, S. (2009) 'Beliefs of small, independently owned rural retailers about internet use: A Typology', Paper presented to the AMS/ACRA Fall Triennial Retailing Conference New Orleans

Strauss, A. and J. Corbin (1998). 'Basics of Qualitative Research: Techniques and Procedures for Developing Grounded Theory’2nd edn. Thousand Oaks, CA: Sage

Stranahan, H. and Kosiel, D. (2007) "E-tail spending patterns and the importance of online store familiarity", Internet Research, 17 (4) 421 - 434

Weltevreden, J. (2006) Substitution or complementarity? How the Internet changes city centre shopping, Journal of Retailing and Consumer Services 14 (192 - 207).

Weltevreden, J., Atzema, O., Frenken, K., de Kruijf, K. and van Oort, F. (2008). The geography of Internet adoption by independent retailers in the Netherlands. Environment \& Planning B, 35 (3), 443-460

Ylijoki O. (2005) Academic nostalgia: a narrative approach to academic work. Human Relations 58: 555-576 
Table One: Selected mainland retailers island delivery policies.

\begin{tabular}{|c|c|c|c|c|c|}
\hline $\begin{array}{l}\text { Product } \\
\text { Category } \\
\text { and } \\
\text { Retailers } \\
\end{array}$ & $\begin{array}{l}\text { Deliver } \\
\text { to } \\
\text { Islands }\end{array}$ & $\begin{array}{l}\text { Standard Delivery } \\
\text { Costs }\end{array}$ & $\begin{array}{l}\text { Additional } \\
\text { Delivery } \\
\text { Costs to } \\
\text { Islands } \\
\end{array}$ & $\begin{array}{l}\text { Delivery } \\
\text { Method(s) }\end{array}$ & $\begin{array}{l}\text { Additional Conditions of Island deliveries } \\
\text { (Comments from retailers' website ) }\end{array}$ \\
\hline $\begin{array}{l}\text { Dorothy } \\
\text { Perkins }\end{array}$ & Yes & $\begin{array}{l}\text { Free on orders over } \\
£ 75 \text {. }\end{array}$ & None. & Couriers. & $\begin{array}{l}\text { Standard orders within } 7 \text { working days to the Highlands and } \\
\text { Islands. During busy periods, please allow up to } 10 \text { working days. }\end{array}$ \\
\hline River Island & Yes & $\begin{array}{l}\text { Standard delivery } \\
£ 3.95 \text {. }\end{array}$ & None. & Couriers. & $\begin{array}{l}\text { Standard delivery within } 3-4 \text { working days, deliveries to The } \\
\text { Scottish Highlands, Scottish Islands, the Isle of Wight, Isle of Man } \\
\text { and Northern Ireland will take longer. }\end{array}$ \\
\hline Schuh & Yes & $\begin{array}{l}\text { Free on items priced } \\
\text { over } £ 14.95 \text {. }\end{array}$ & None. & Couriers. & \\
\hline Argos & No & $\begin{array}{l}\text { Small items } £ 5.95 \text {, } \\
\text { Large items } £ 8.95 \text {. }\end{array}$ & $\begin{array}{c}\text { Not } \\
\text { applicable. }\end{array}$ & $\begin{array}{l}\text { Royal Mail or } \\
\text { courier. }\end{array}$ & $\begin{array}{l}\text { Unable to deliver to the Isle of Man, Isles of Scilly, Orkney, } \\
\text { Shetland and Western Scottish Islands, BFPO addresses, or the } \\
\text { Republic of Ireland. }\end{array}$ \\
\hline Next & Yes & $\begin{array}{l}\text { Delivery charge to } \\
\text { mainland UK } £ 3.99 \\
\text { (exceptions listed in } \\
\text { T\&Cs). }\end{array}$ & $\begin{array}{l}\text { Additional } \\
\text { charges for } \\
\text { selected } \\
\text { large items } \\
\text { outside } \\
\text { mainland. }\end{array}$ & $\begin{array}{l}\text { Personal courier } \\
\text { service, or 'by } \\
\text { another carrier'. }\end{array}$ & $\begin{array}{l}\text { Northern Ireland, Scottish Highlands and Islands, Isle of Man and } \\
\text { the Channel Islands, delivery will take an extra day. Delivery times } \\
\text { cannot be guaranteed. DVDs, Music \& Blu-ray not delivered } \\
\text { outside mainland UK. }\end{array}$ \\
\hline
\end{tabular}




\begin{tabular}{|c|c|c|c|c|c|}
\hline & & & UK: & & \\
\hline Homebase & No & $\begin{array}{l}\text { Delivery costs will be } \\
£ 5.95 \text { for small items } \\
\& £ 8.95 \text { for larger } \\
\text { items. }\end{array}$ & $\begin{array}{l}\text { Not } \\
\text { applicable. }\end{array}$ & $\begin{array}{l}\text { Courier or direct } \\
\quad \text { from a } \\
\text { manufacturer } \\
\text { (larger items). }\end{array}$ & $\begin{array}{l}\text { Do not deliver to the Channel Islands, Isle of Man, Orkney, } \\
\text { Shetland and Scottish Islands, BFPO addresses, or the Republic of } \\
\text { Ireland. }\end{array}$ \\
\hline Currys & Yes & Free. & None & Courier. & $\begin{array}{l}\text { Large products delivered to all UK addresses excluding the Channel } \\
\text { Islands, the Isle of Man and BFPO. }\end{array}$ \\
\hline HMV & Yes & Free. & None & UK Mail. & \\
\hline Amazon & Yes & $\begin{array}{l}\text { Dependent upon } \\
\text { item. }\end{array}$ & None & $\begin{array}{l}\text { Royal Mail or } \\
\text { carrier. }\end{array}$ & Certain large items can only be delivered to mainland UK. \\
\hline DFS & Yes & Dependent upon item. & Yes & $\begin{array}{l}\text { Depends upon } \\
\text { product. }\end{array}$ & $\begin{array}{l}\text { Free delivery applies to UK mainland addresses only. Scottish } \\
\text { Islands, Channel Islands, Isle of Man, Isle of Wight and Northern } \\
\text { Ireland, incur additional delivery charge. This charge is dependant } \\
\text { on location and the type of product ordered. }\end{array}$ \\
\hline $\begin{array}{l}\text { Reid } \\
\text { Furniture }\end{array}$ & No & Dependent upon item. & $\begin{array}{l}\text { Depends } \\
\text { upon local } \\
\text { carriers. }\end{array}$ & Own transport. & $\begin{array}{l}\text { Unable to deliver to the more remote parts of Scotland, or any of } \\
\text { the outer islands. Option however for customer to pick up from an } \\
\text { Inverness collection points. }\end{array}$ \\
\hline ASDA & Yes & $\begin{array}{l}\text { Standard Delivery - } \\
\quad £ 2.95 .\end{array}$ & Yes & $\begin{array}{l}\text { Own vehicles } \\
\text { and couriers. }\end{array}$ & $\begin{array}{l}\text { Majority of products delivered to all of the UK, but for Islands and } \\
\text { Northern Ireland, additional costs apply. }\end{array}$ \\
\hline
\end{tabular}

Source: various retailer websites 
Table Two: Island Types

\begin{tabular}{|l|l|l|}
\hline Type & Criteria & Examples \\
\hline One & $\begin{array}{l}\text { Has at least one established retail centre } \\
\text { with national retail multiples present. }\end{array}$ & $\begin{array}{l}\text { Isle of Lewis and Harris, Isle of } \\
\text { Man, Shetland Mainland. }\end{array}$ \\
\hline Two & $\begin{array}{l}\text { Islands with retail presence but no } \\
\text { national multiple retailer. }\end{array}$ & Isle of Ghia, Isle of Rhum. \\
\hline Three & Islands with no formal retail provision. & Isle of Muck, Papa Stour. \\
\hline
\end{tabular}


Table Three. Main forms of retail provision in island communities.

\begin{tabular}{|l|l|}
\hline Channel & Comments \\
\hline $\begin{array}{l}\text { Retail stores in main } \\
\text { town }\end{array}$ & $\begin{array}{l}\text { National multiple retailers such as Co-op, Tesco and Boots have } \\
\text { physical presence on larger UK islands. Some multiples offer } \\
\text { home delivery service but not an on-line grocery service. }\end{array}$ \\
\hline Local retail provision & $\begin{array}{l}\text { Primarily small independent shops selling eclectic mix of } \\
\text { products such as grocery, petrol and limited hardline goods. }\end{array}$ \\
\hline Product Fairs & $\begin{array}{l}\text { Yearly product fairs organised by major retailers. Although once } \\
\text { very popular, its popularity now considered to be in decline. }\end{array}$ \\
\hline Catalogues & $\begin{array}{l}\text { Traditionally the primary form of non store retail provision } \\
\text { amongst island communities. }\end{array}$ \\
\hline Mobile shop & $\begin{array}{l}\text { Small number of providers offering mainly grocery products. } \\
\text { Visit to each location varies but approximately 1 - 2 times a week. } \\
\text { Operator may also have own independent store. }\end{array}$ \\
\hline $\begin{array}{l}\text { Shopping trips off the } \\
\text { island }\end{array}$ & $\begin{array}{l}\text { Many island residents have traditionally made one or two trips } \\
\text { per annum to the mainland (often before the start of the school } \\
\text { term and at Xmas). }\end{array}$ \\
\hline Order and Collect & $\begin{array}{l}\text { Individual places an advert in local newspaper. Collects orders on } \\
\text { behalf of many residents, travels to mainland, purchases products } \\
\text { and charges commission (e,g. 20\%). }\end{array}$ \\
\hline Door to door & $\begin{array}{l}\text { Individuals selling products from a car / suitcase. Still occurs } \\
\text { around once a year. Selling small household items such towels / t- } \\
\text { towels. }\end{array}$ \\
\hline Party Planning & $\begin{array}{l}\text { Individuals host parties in their own home or become the local } \\
\text { consultant / representative for the brand. }\end{array}$ \\
\hline Internet & $\begin{array}{l}\text { Widely adopted by island residents. Variety of products } \\
\text { purchased and websites used. }\end{array}$ \\
\hline
\end{tabular}

Source: Respondent Interviews 
Table Four Reasons for purchasing via internet.

\begin{tabular}{|c|c|c|c|}
\hline & $\begin{array}{l}\text { Reasons for using } \\
\text { Internet }\end{array}$ & $\begin{array}{l}\text { Reasons for not using } \\
\text { Internet }\end{array}$ & Comments \\
\hline Grocery & $\begin{array}{l}\text { Availability and Range. } \\
\text { Specialist items such as } \\
\text { deli products, wines by } \\
\text { the case. }\end{array}$ & $\begin{array}{l}\text { Majority of retailers do } \\
\text { not offer on-line } \\
\text { ordering facility. }\end{array}$ & $\begin{array}{l}\text { The overwhelming majority of } \\
\text { grocery products bought via a } \\
\text { physical outlet. Some island } \\
\text { retailers offer home delivery. }\end{array}$ \\
\hline $\begin{array}{l}\text { Soft } \\
\text { Furnishings }\end{array}$ & $\begin{array}{l}\text { Price and Range. } \\
\text { Possible to save up to } \\
50 \% \text { on local prices plus } \\
\text { wider range available. }\end{array}$ & & $\begin{array}{l}\text { Noted amongst some older } \\
\text { residents that catalogues } \\
\text { traditionally been used to buy soft } \\
\text { furnishings prior to internet. }\end{array}$ \\
\hline $\begin{array}{l}\text { Perfumes / } \\
\text { Cosmetics }\end{array}$ & $\begin{array}{l}\text { Choice. Allow specific } \\
\text { brands to be chosen and } \\
\text { undertake repeat } \\
\text { purchases. }\end{array}$ & $\begin{array}{l}\text { As only purchased } \\
\text { occasionally, products } \\
\text { bought when visiting } \\
\text { towns. }\end{array}$ & \\
\hline Furniture & $\begin{array}{l}\text { Price. Cost savings } \\
\text { considered to be } \\
\text { significant. }\end{array}$ & $\begin{array}{l}\text { Need to see product. } \\
\text { Cost of delivery from } \\
\text { mainland can be } \\
\text { prohibitive. }\end{array}$ & $\begin{array}{l}\text { Greater willingness to use internet } \\
\text { when buying for business. For } \\
\text { example office equipment or } \\
\text { furniture for holiday let. }\end{array}$ \\
\hline Clothing & $\begin{array}{l}\text { Cost, Range and } \\
\text { Convenience. Able to } \\
\text { buy products when } \\
\text { needed. }\end{array}$ & $\begin{array}{l}\text { Not wish to have to re- } \\
\text { package and return. } \\
\text { Important to try certain } \\
\text { products before } \\
\text { purchase. }\end{array}$ & $\begin{array}{l}\text { Internet heavily used by the } \\
\text { majority of respondents. Exception } \\
\text { appeared children's shoes. }\end{array}$ \\
\hline $\begin{array}{l}\text { Kitchens / } \\
\text { Bathrooms }\end{array}$ & $\begin{array}{l}\text { Cost and available } \\
\text { styles. }\end{array}$ & $\begin{array}{l}\text { Service. Need for expert } \\
\text { advice to ensure buying } \\
\text { right type of products. }\end{array}$ & $\begin{array}{l}\text { More likely to use internet if } \\
\text { purchasing for house rental. }\end{array}$ \\
\hline $\begin{array}{l}\text { Carpets / } \\
\text { floor } \\
\text { coverings }\end{array}$ & Cost and range. & $\begin{array}{l}\text { Important to see sample } \\
\text { and discuss sizes and } \\
\text { fittings with seller. }\end{array}$ & \\
\hline Newspaper & Convenience. & & $\begin{array}{l}\text { Allows instant access to news and } \\
\text { related coverage }{ }^{1} \text {. }\end{array}$ \\
\hline Electronic & Price. & $\begin{array}{l}\text { Service. Need for expert } \\
\text { advice when buying and } \\
\text { after sales service. }\end{array}$ & $\begin{array}{l}\text { Concern expressed about the after } \\
\text { sales services offered by mainland } \\
\text { and / or web based retailers. }\end{array}$ \\
\hline $\begin{array}{l}\text { Music \& } \\
\text { Games / } \\
\text { CD/DVD }\end{array}$ & Availability and choice. & $\begin{array}{l}\text { Impulse. Bought while } \\
\text { respondents were in } \\
\text { town. }\end{array}$ & \\
\hline White goods & $\begin{array}{l}\text { Price. Local retailers } \\
\text { noted to be more } \\
\text { expensive (up to 25\%). }\end{array}$ & $\begin{array}{l}\text { After sales service led } \\
\text { many opt for island } \\
\text { stores. }\end{array}$ & $\begin{array}{l}\text { Concern expressed about the after } \\
\text { sales services offered by mainland } \\
\text { and / or web based retailers. }\end{array}$ \\
\hline Services & Cost and choice. & $\begin{array}{l}\text { Service. Travel Agents } \\
\text { able to offer better } \\
\text { service. }\end{array}$ & $\begin{array}{l}\text { Purchase of flights, holidays, } \\
\text { insurance and car tax on-line } \\
\text { widespread. }\end{array}$ \\
\hline $\begin{array}{l}\text { Other } \\
\text { specialist } \\
\text { products }\end{array}$ & $\begin{array}{l}\text { Availability. Access to } \\
\text { goods previously } \\
\text { difficult to source or } \\
\text { unattainable. }\end{array}$ & & $\begin{array}{l}\text { Examples include: wedding cake } \\
\text { decoration site, suppliers to create } \\
\text { bespoke hats. Antique golf clubs. }\end{array}$ \\
\hline
\end{tabular}

\footnotetext{
${ }^{1}$ Because of the remote location of many island communities newspapers are regularly delivered late. For example, the Sunday papers arrive after three pm on Monday and are still for sale on the Thursday. One respondent now subscribed to the Times / Telegraph and Daily Mail and was able to gain instant access to all three publications.
} 
